\title{
Interface of Geodiversity, Geomorphosites, Geotourism and Seasonal Economy in Lahaul and Spiti, Himachal Pradesh, India
}

\author{
Krishnanand \\ Department of Geography, Delhi School of Economics, University of Delhi, India, krishna.geography@gmail.com
}

\begin{abstract}
Interface of Geodiversity with human response can be understood simply as, the natural range (diversity) of geological (rocks, minerals, fossils), geomorphological (landforms, topography, physical processes), soil and hydrological features including their assemblages, structures, systems and contributions to landscapes together with the anthropogenic amalgamation in the landscape system. Geomorphosites are those components of geodiversity that have acquired a scientific, cultural/historical, aesthetic and socio-economic value due to human perception or exploitation (Panizza, 2001). The trans-Himalayan district of Lahaul and Spiti, Himachal Pradesh, India is a landlocked district in trans-Himalaya accessible seasonally through high mountain passes; where the interface is manifested though human response to the geodiversity elements. The abiotic factors play a significant role in generating stimuli and the human response varies accordingly in the study area. It is also known as the Tethyan Himalayan region, where the interface (interactive zone/ crossing point/edge) of Geomorphosites and human response in terms of geotourism has been analysed and mapped. The data has been collected through extensive field work using structured questionnaire survey and field observations at geomorphosites having unique characteristics. The field work has been done in May-June 2017 and June 2018. The assessment of human response in terms of seasonal economy and geotourism has been done using GIS environment, GPS and SWOT analysis. The study highlights that potential geotourism sites have to be further identified, explored and developed in the region and the existing sites have to be conserved in order to harness the tremendous geotourism potential of the region and thereby boosting the seasonal economy.
\end{abstract}

Key words: geodiversity, geotourism, geomorphosites, Trans-Himalaya, seasonal economy

\section{Introduction}

The interest in geotourism is rapidly increasing at places with higher geodiversity (geosites, geomorphosites). There are certain concepts that define a geomorphosite, meaning that this feature must be a landform which we can attribute a certain value and must be a geomorphological resource which can be used by the society (Panizza 2001). Many of these values may be very subjective when we consider the importance of such a geomorphosite. The scientific, cultural and ecological values may be easier to evaluate based on their objectivity. On the other hand, the aesthetic is a very subjective value, given only by the personal perception, by the individual consideration and feelings (Panizza 2001). Also, the economic value attached with it is very subjective in nature because some economic factors may lead to exploitation of a certain geomorphosite and generate quick income, at the same time being at the risk of being destroyed, or the reverse, to get incomes for longer periods, but with the main aim of preserving that landform.
In regards to the definition; a geomorphosite is defined as a landform with unique and significant geomorphological attributions that qualify it as a component of a region's cultural heritage. In the analysis of the geomorphosites there shall always be the problem of subjectivity because the knowledge and the experience of the observer tend to define the site in context to such geomorphological heritage (Panizza 2001). The value of geomorphosites can be scientific/ educational, intrinsic, cultural, aesthetic, economic and functional (Gray 2013) as well as ecological (Reynard et al. 2007). Several classification and assessment methods have been suggested and used since the term geomorphosites was introduced by Panizza (2001). He suggested the assessment of the geomorphosites on the basis of scientific criterion (as a model of geomorphological process or as an ecological support), pertinence (world-wide to local), the degree of preservation (well-preserved to poorly preserved), and the degree of damage (nil to destroyed). Coratza and Giusti (2005) conceptualised a methodology to assess the scientific quality of a geomorphosite in terms of 
weighted mean, on the basis of seven characteristics namely educational value, value for the scientific research, areal extent rareness, exposure, integrity and the added value. In another study, Reynard et al. (2007) based their assessment on five criteria:

1. Scientific value (integrity, representativeness, paleogeographical value, and rareness),

2. Ecological value (ecological impact and protected species),

3. Aesthetic value (number of viewpoints, contrasts, vertical development),

4. Cultural value (religious, historical and artistic importance), and

5. Economic value (economic products).

Pereira and Pereira (2010) suggested an assessment methodology for potential geomorphosites based on three principal criteria - geomorphological intrinsic value (scientific and other geomorphological values), potential use (accessibility, visibility and use of other natural or cultural values), and need for protection (deterioration and vulnerability). Bruschi et al. (2011) proposed a parametric method based on three sets of criteria: intrinsic quality, potential for use and protection needs. Hassan et al. (2012) used the Analytic Hierarchy Process (AHP) to assess geosites using multiple attributes (climate, topography, geomorphology, infrastructure, safety, distance, etc.).

Landforms are potential resources for geotourism which, following the assessment of their scientific value, become steady resources or geomorphosites. As an adequate management framework is implemented (hereby including good quality infrastructure, general and specific services and facilities), geomorphosites become authentic geotourism products (Neches 2013). Comanescu and Nedelea (2010), quoting Panizza and Piacente (2003) mention that geomorphosites are represented by those landforms that in time, have acquired, a certain value, naming here scientific, cultural, aesthetic, ecological and/or economic.

Geomorphosites are also defined as the geomorphological landforms which have gained scientific, historical, cultural, aesthetic or socioeconomic value due to human knowledge and exploitation (Shayan et al. 2011). Therefore, geomorphosites in combination with cultural, historical and ecological heritage would have great potential in the development of sustainable geotourism.

Geological and geomorphological processes with high scientific and educational interest can be associated to aesthetics/monumentality and become geomorphosites or geosites with tourist potential. Geotourism is defined as tourism which focuses on an area's geology and landscape as the basis of fostering sustainable tourism development. It begins with an understanding of the abiotic (non-living) environment, to build greater awareness of the biotic (liv- ing) environment of plants and animals as well as the cultural environment of people (Dowling 2013). Hence, both geological and geomorphological features are of paramount importance in understanding geotourism. Yamani et al. (2012) studied the tourism potentials of some geomorphosite of Guilan province applying Pralong and Pereira models and suggest that among the studied geomorphosites, raised beaches got the highest score and muds got the lowest score in tourism development. Geotourism is intended to stimulate the knowledge of geodiversity, geoconservation and use them for sustainable development.

Now, looking at geodiversity, it has been defined as the natural range (diversity) of geological (rocks, minerals, fossils), geomorphological (landforms, topography, physical processes), soil and hydrological features. It includes their assemblages, structures, systems and contributions to landscapes (Zwoliński 2004, Gray 2013, p.12). The concept of geodiversity include an appreciation of the geological and physical minerals, rocks, soils, fossils and landforms, and the active geological and geomorphological processes that characterise the underground (Coratza et al. 2018).

Geotourism tends to explore the establishment of geoparks as high quality destinations for alternative sustainable tourism, to promote recent developments in protection and promotion of natural heritage in combination with local development as well as in management and operation of Geoparks. In their study, Pica et al. (2016) enhanced geotourism in the city centre, by describing the palaeogeography of ancient Rome through the landforms that were still visible and identified two geomorphosites. In their investigative attempt, Pica et al. (2016) developed an evaluation model of the Geotouristic Value of a Site (VSG index), which consisted of the quantification of five fundamental attributes for a geosite, characterising its scientific and geotourist interests.

The present study locates itself amid all the mentioned concepts worldwide in the context of the trans-Himalayan district of Lahaul and Spiti, Himachal Pradesh, India. It is a landlocked district; accessible seasonally through high mountain passes; where the interface of geodiversity elements and human response is manifested though geotourism and allied activities. The abiotic factors play a significant role in generating stimuli and the human response varies accordingly in the study area.

\section{Research methodology}

The objective of the study is to identify and analyse the linkages (interface) between geotourism (tourism based on geomorphosites) and seasonal economy in Lahaul and Spiti district of Himachal Pradesh. 
The study is based on primary data collected during the field visits to Lahaul and Spiti during 2017 and 2018. Primary data sources include the field observation tables collected through extensive field survey that includes in-depth interviews and observations through photographs in the study area. For the analysis of seasonal economy based on dhaba (a roadside food stall having bedding and camping facilities for the travellers along with other necessary goods such as woollens, shoes, socks, torches, batteries and edible items); a survey based on applying open-ended questionnaire was conducted during the various field visits in both opening and closing season in 2017-2018. It is also referred commonly as Tethyan-Himalaya, where the interface (interactive zone/ crossing point/edge) of geodiversity (geomorphosites and geosites) has been analysed and mapped using GPS and GIS software. Likert scale (high, medium, low) has been used to analyse and present the levels of geotourism in the study area.

\section{Study area}

(acc. to Krishnanand, Raman 2019)

Lahaul and Spiti district of Himachal Pradesh, India (Fig. 1) is a land of high mountain passes that act as gateway for accessibility. Though it is administratively a single district, but physiographically it has two sub-parts i.e. western part is called Lahaul and eastern part is called Spiti; separated by Kunzum pass. The district has an inherent seasonality in character due to the seasonal opening of mountain passes and thereby exchange of goods and services during this fixed time period. The Rohtang pass and the Baralacha pass are the most prominent passes in the district (Fig. 2). Rohtang pass in the eastern Pir-Panjal range of greater Himalaya, connects Kullu district to Lahaul and Spiti district while Baralacha pass is the gateway from Lahaul and Spiti district to Ladakh district. Hence, these passes facilitate inter-district accessibility for tourists. The tentative time period of opening of these passes varies between $20^{\text {th }}$ May to $5^{\text {th }}$ June every year depending upon the climatic conditions and they close by $15^{\text {th }}$ October. Therefore, the season for various activities including business and tourism is confined to these four months of June, July, August and September.

Lahaul and Spiti district falls in the rain shadow area of the Great Himalayan Range, restricting the monsoon winds to traverse through. This gives the district a unique cold desert character. In Lahaul valley, annual rainfall varies from about 10 to $40 \mathrm{~cm}$. Southern and south western part of the Lahaul valley receive more rainfall compared to the northern part. In Lahaul valley, the snowfall varies from less than $1 \mathrm{~m}$ to $6 \mathrm{~m}$ and may be higher at higher altitudes. Maximum temperature at Keylong (headquarter of Lahaul and Spiti district) ranges between $7{ }^{\circ} \mathrm{C}$ and

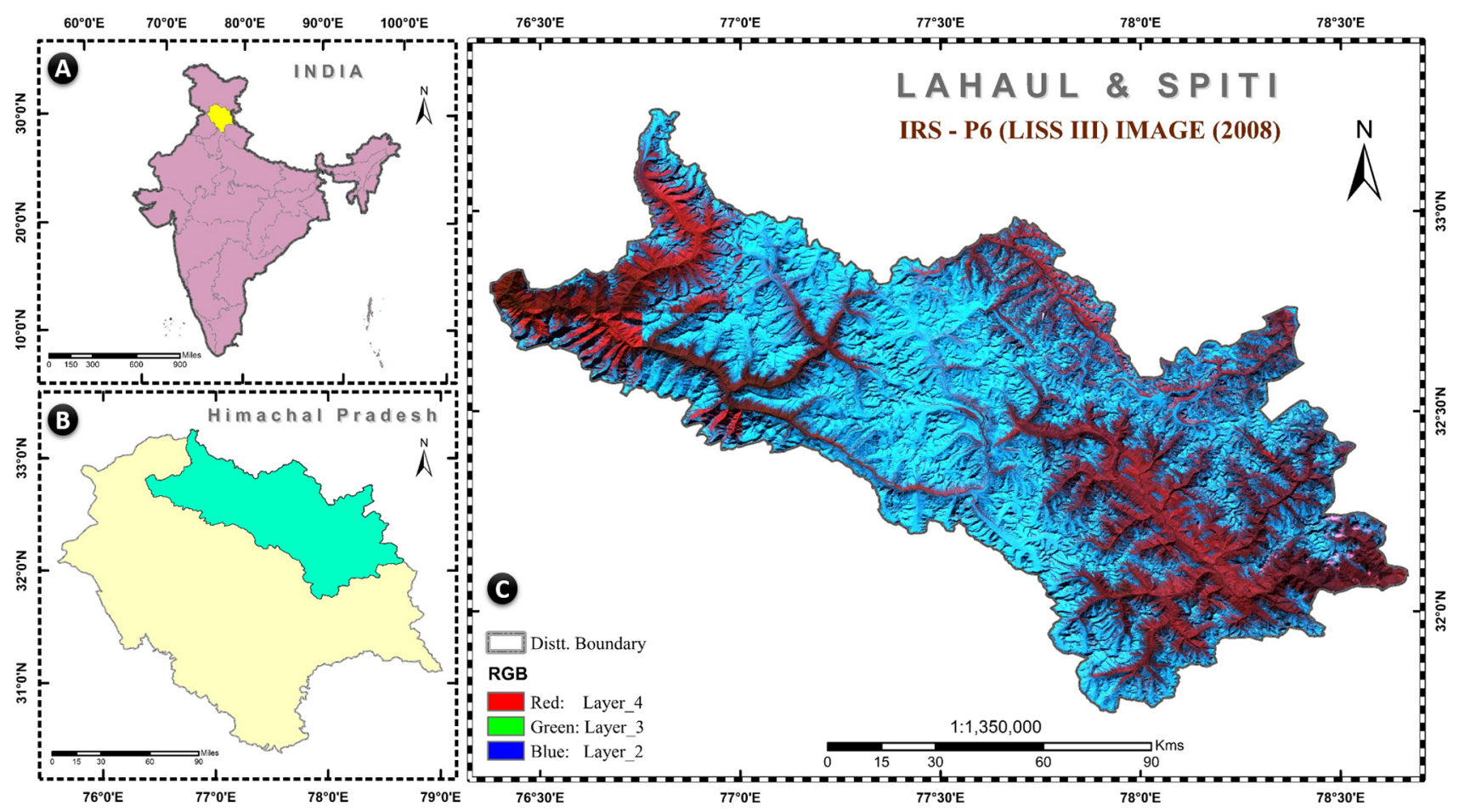

Fig. 1. Location of Lahaul and Spiti, Himachal Pradesh, India (acc. to: Survey of India and IRS LISS III Imageries from BHUVAN, IRSO) (Krishnanand, Raman 2019)

A - Position of Himachal Pradesh in India, B - Position of Lahaul and Spiti in Himachal Pradesh, C - Lahaul and Spiti (LISS III extract view) 
$23{ }^{\circ} \mathrm{C}$ while minimum temperature from $-10{ }^{\circ} \mathrm{C}$ to $+10{ }^{\circ} \mathrm{C}$ in the month of February and July respectively. The word Spiti is pronounced as Piti in local language which literally means middle country. The name signifies its geographical location i.e. it lies in the middle of greater Himalaya and Tibetan plateau. Geologically, the district can be seen as a living museum by the virtue of being core of Tethyan Himalaya. The Spiti (eastern part) is $3900 \mathrm{~m}$ above m.s.l. whereas the Lahaul (western part) is 3300 above m.s.l. in terms of average altitude.

As per 2011 census, entire (100 per cent) population of Lahaul and Spiti district live in rural areas as there is no urbanisation. The district accounted for the second lowest population for any district in India in 2001 census and is the least populous district in the country according to the 2011 census since its population has declined from 33,224 in 2001 to 31,528 in 2011. The district's geographical area is 24.85 per cent of the total area of Himachal Pradesh; that means, about quarter of the State's area is commanded by this district. Hence, it is the biggest district by geographical area in the State and is the 17th largest district in India.

The people of Lahaul and Spiti are both Hindus and Buddhists, and their dialect is Indo-Tibetan. They have a close affinity with Ladakhis and Tibet- ans. The people and the culture in the region evolved over the centuries in isolation, from the rest of the world. In 1992-93, Government of India lifted all the restrictions, including for foreigners, for travelling into the ancient Kingdom of Lahaul and Spiti, which has been virtually forbidden to outsiders for over 30 years since 1962 i.e. during Indo-China war.

\section{Results and discussions}

As, the trans-Himalayan district of Lahaul and Spiti, Himachal Pradesh, is devoid of modern technological stimuli due to its landlocked situation and remoteness; it is only accessible through seasonal opening of mountain passes. Therefore, in this part of the Trans-Himalaya, the abiotic factors, i.e. geodiversity and geomorphosites provide the stimuli and the human response varies accordingly (Fig. 3). Seasonality in economy is one such human response that is manifested through geotourism in the area that is based on the unique geomorphosites.

The samples for the study were based purely on the location (geomorphosites) in order to understand the relationship (interface) of dhaba economy with geotourism. The dhabas of Lahaul (western part) in-

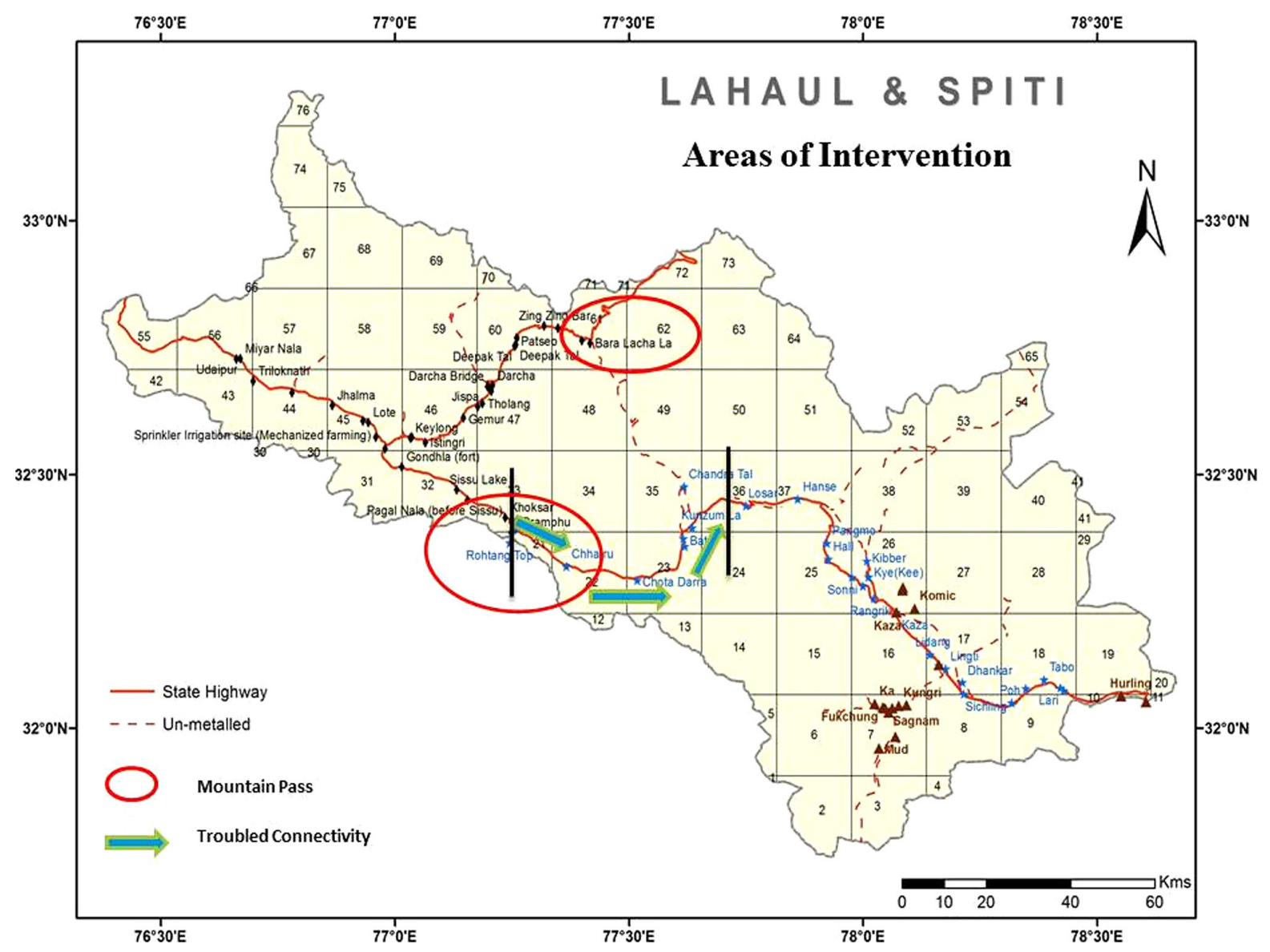

Fig. 2. Areas of intervention in Lahaul and Spiti: Mountain Passes and Troubled Connectivity 


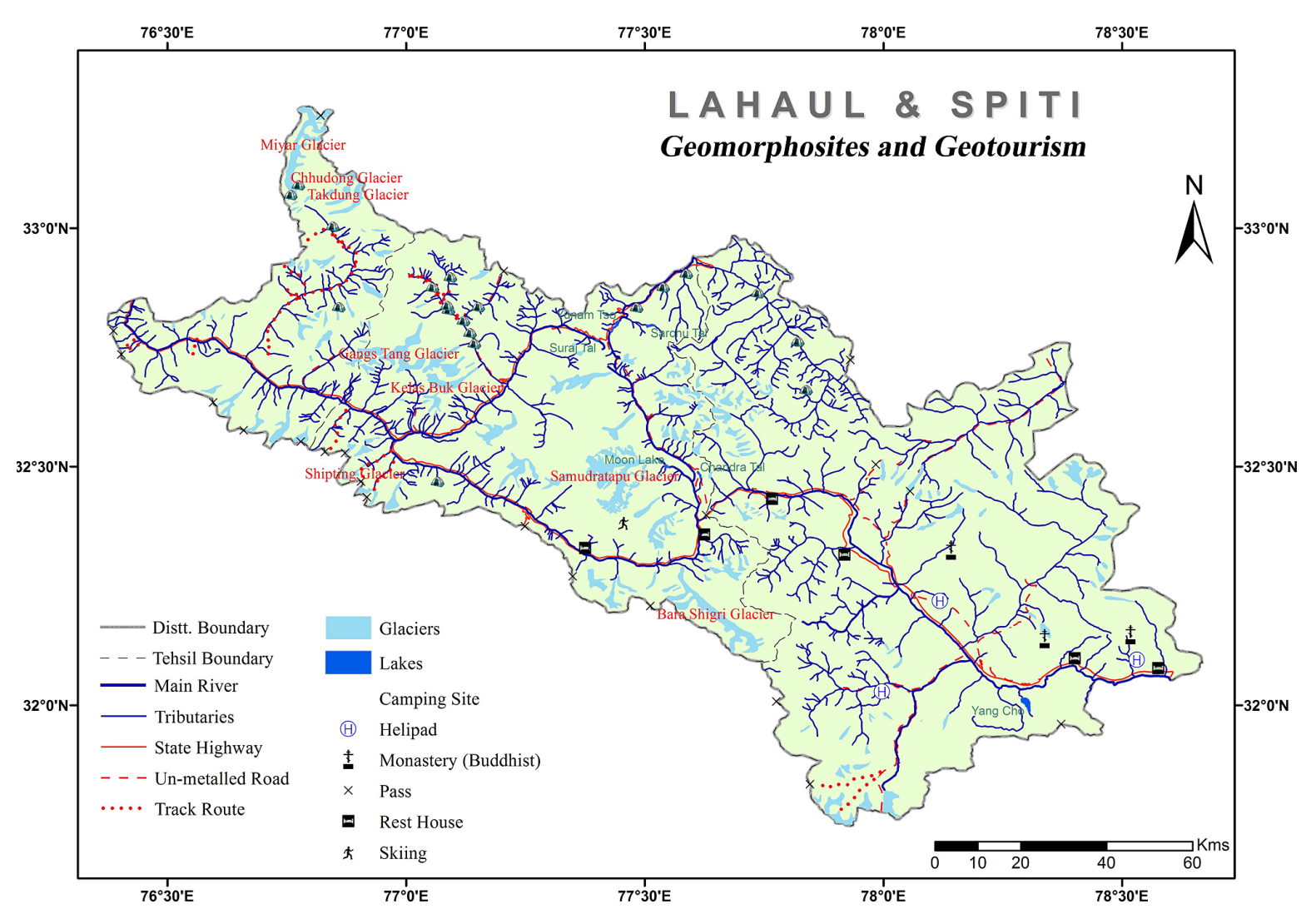

Fig. 3. Location and distribution of geomorphosites in Lahaul and Spiti (Krishnanand, Raman 2019)

clude the locations such as Gramphu, Tandi, Udaipur, Thirot, Darcha, Zing-Zing Bar, Chhatru and Batal while the locations in Spiti (eastern part) include Losar, Kibber, Kaza, Langza, Komic, Tabo, Hurling, Sagnam and Mud. The locations of these places have been mapped using the coordinate points marked through GPS (global positioning system) during the field survey on free source web GIS (geographic information system) software.

The main source of livelihood for the local communities are agriculture and allied activities; and the main occupations include animal husbandry, daily wage earning as labourers in government programs, regular government service, business (mainly shop keeping), crafts like weaving while very few people are involved in the travel and tourism industry (geotourism) which is recently gaining significance in this region.

The various geomorphosites have been put together in the map and the zonations based on geotourism have been made (Fig. 4). The scale of zonation is based on number of tourist influx. Zone I has maximum whereas Zone $\mathrm{V}$ has minimum geotourism. The zonations of these geotourism destinations are as follows:

- Zone I: Batal, Chandra Tal, Kunzum pass

- Zone II: Langza, Kaza, Kibber, Komic

- Zone III: Baralacha pass, Sarchu

- Zone IV: Tandi, Keylong
- Zone V: Pin Valley, Mud

- Zone VI: Tabo, Lari, Sumdo

In the selected samples of geomorphosites (Table 1 ), only couple of sites have been considered for geoconservation by the government yet. The selection of sample was purely on the basis of the established tourism circuit by the department of tourism, government of Himachal Pradesh, India. Many of these sites have high potential to be converted into fossil parks or geoparks depending upon the Values (scientific or cultural) ascribed to them (Fig. 5).

The seasonal tourist influx together with the communities that carry out various businesses and earn seasonal livelihood, generate a huge demand for refreshments (food, water and other day to day utilities) during their treacherous journey in the difficult terrain of Lahaul and Spiti district. This seasonal mechanism of demand is fulfilled by the supply through various dhabas that are lifeline for the commuters, explorers and travellers in the district.

The area is characterized by seasonality which is evident from the fact that these dhabas open every year at the start of the season and continue throughout the four months with reinforced supplies from the adjoining areas i.e. Kullu and Kinnaur districts as the roads are open and transportation is easily available. They have a unique setup in which food and shelter both are available for the guests with minimal charges. After the detailed study of these dhabas in Lahaul 
and Spiti through structured and open-ended questionnaire surveys, it can be inferred that the Lahaul (western part) has larger number of guests at their dhabas in comparison to Spiti (eastern part). The main reason for this is the manali-leh high way (running through Rohtang pass and Baralacha pass), along which these dhabas are located i.e. geo-Zone III and IV. These dhabas have lesser income levels and dividends than that of geo-Zone I, II, V and VI as they are more dependent upon the snow clearance at these mountain passes and stability in roads condition.

The challenges as highlighted while conducting the interviews (during the field work) with dhaba owners are mainly ascribed to the difficulties in restoration of these temporary structures, construction of newer ones in many cases and the transportation of the goods to these remote areas. They hire mules in few cases while the most of them hire tempo travellers and tractors that are very expensive. Secondly, the problem of labour is faced specially by the local dhaba owners, as they have to negotiate with the season labourers coming mostly from Nepal and other states of India such as Bihar, Odisha and Uttar Pradesh, who charge them heavily for construction work. The people of Lahaul and Spiti build their houses using locally available stones, soil (rich in gypsum and lime) and local wood (usually poplar trees) and in some cases; with tin shades for roofing clearly depicting the interface of geodiversity and human response. Another significant issue that is

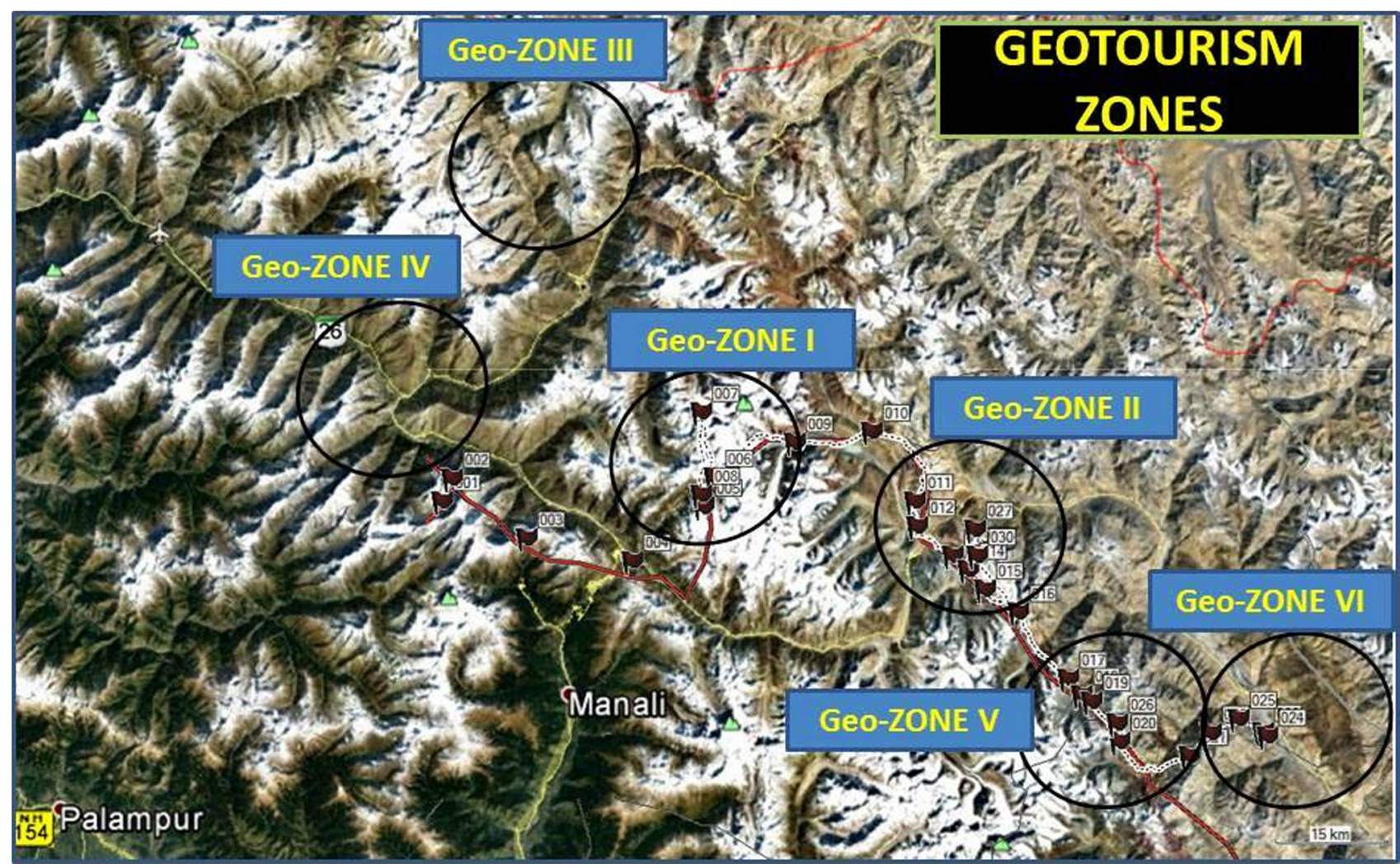

Fig. 4. Geotourism zones of Lahaul and Spiti

Table 1. Some examples of existing and potential geomorphosites in Lahaul and Spiti

\begin{tabular}{|c|c|c|c|c|c|}
\hline Geomorphosites & Location & Landforms & Value (scientific/additional) & $\begin{array}{l}\text { Level of Tourism } \\
\text { Associated (high/ } \\
\text { medium/low) }\end{array}$ & $\begin{array}{l}\text { Measures taken by } \\
\text { Local/Government for } \\
\text { Conservation (if any) }\end{array}$ \\
\hline Chandra Tal & Lahaul & Glacial lake & $\begin{array}{l}\text { Paleo-glacial studies and } \\
\text { site for Transhumance }\end{array}$ & High & $\begin{array}{l}\text { Yes, (Ramsar } \\
\text { Convention Site) }\end{array}$ \\
\hline Suraj Tal & Lahaul & Glacial lake & Source of the river Chenab & Medium & No \\
\hline Dhankar lake & Spiti & Glacial lake & Paleo-glacial studies & Medium & $\begin{array}{l}\text { Yes, World Monument } \\
\text { Fund }\end{array}$ \\
\hline Dhankar Spur & Spiti & Yardangs & Tethyan Sediments & Low & No \\
\hline $\begin{array}{l}\text { Langza (Hanging } \\
\text { Valley) }\end{array}$ & Spiti & $\begin{array}{l}\text { Fossil Park } \\
\text { (table land) }\end{array}$ & $\begin{array}{l}\text { Ammonites, Terebratulids, } \\
\text { Belemnites }\end{array}$ & Medium & No \\
\hline Kyoto Spur & Spiti & $\begin{array}{l}\text { Lacustrine } \\
\text { Sediments }\end{array}$ & $\begin{array}{l}\text { Source of limestones for } \\
\text { cement industry }\end{array}$ & Low & No \\
\hline
\end{tabular}


highlighted during the field survey includes the ratio of these seasonal establishments between the locals and the outsiders.

The analysis of the sample data gives the result that 60 per cent of these dhabas are run by people from Nepal and lower Himachal Pradesh districts like Mandi and Bilaspur. This leads to the monopoly of the outsiders who have better access to technology and resources and hence the locals who are poor in resources have to suffer as there is tough competition in the business especially during the peak season of June and July when there is maximum tourist influx. The locals have to depend on the external middlemen and labour contractors for the goods and services every season and hence their income levels are less than the outsiders. The price manipulation, lucrative offers for stay and meal together with the customer relations play significant role in the success of the business.

The other important issues are the government facilities of health and sanitation. The toilet and medical facilities are not available at most of these sites and the owners themselves have to make arrangements for the same, which becomes a burden in many cases due to financial crunch. The problem of waste disposal has become alarming by the advent of increasing tourism in last decade. There is lack of dustbins and disposal sites for the large amount of biodegradable as well as non-biodegradable waste, of which the plastic bottles and the wrappers have the largest share. Hence, mostly they are disposed of and buried in the locally created pits at the end of the season.

When asked about the significant changes observed by the owners in last decade, the most significant answer was the increase in number of tourists and considerable growth in business. Hence, they are not willing to switch to any other profession during the season. During off season, the outsider owners go back to their respective base locations and perform labourer jobs and selling of woollen clothes and handicrafts. Many locals also migrate to lower Himachal Pradesh during harsh winters and sell handmade woollen garments.

According to an article (The Times of India 2010), Bodh Dorjee also known as Kakoo, aged 55 at Batal has the biggest and oldest establishment. He comes with his wife Chandra Dorjee (Fig. 6) and few workers during the onset of season when even the motorable roads are not open by hiring mules and stays till late end of the season every year. He has been given a satellite phone by the government in order to serve the locals and the research expeditioners.

The main obstacles in geotourism development as pointed out during the tourist surveys, emphasize upon the poor quality of roads and transport facilities due to treacherous terrain. Only a small frac-

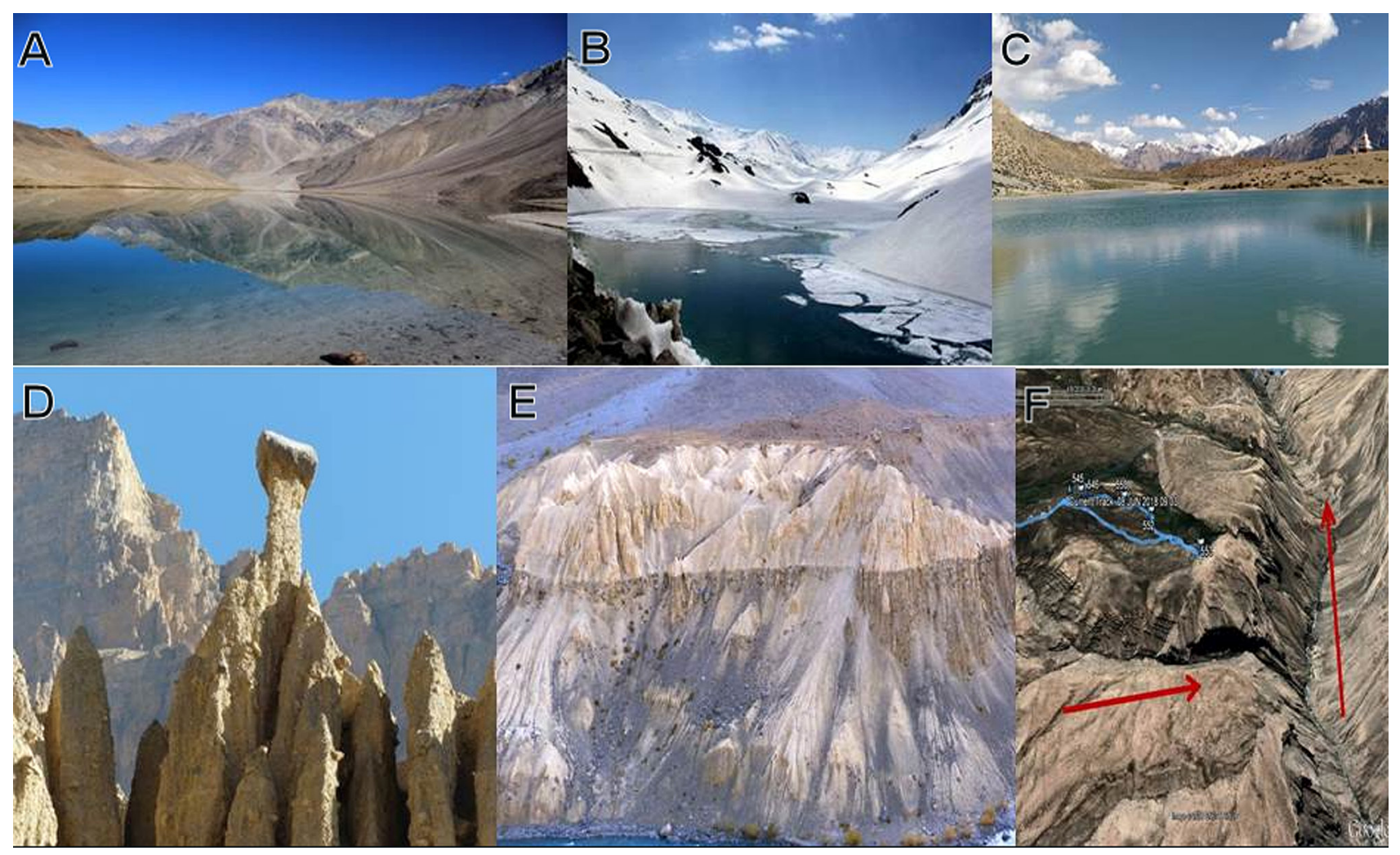

Fig. 5. Some examples of geomorphosites in Lahaul and Spiti

A - Chandra Tal (glacial lake), B - Suraj Tal (glacial lake), C - Dhankar Lake (glacial lake), D - Dhankar Spur (yardangs), E - Kioto Spur (lacustrine sediments), F - Langza (hanging valley) 
tion of tourists also referred to harsh climate, lack of medical facilities and remote location as hindrances for geotourism in the area. Some very important features of geodiversity like fossils (Fig. 7), glacio-fluvial deposits, lacustrine sediments, unnamed waterfalls, highest settlements on almost vertical slopes immense potential to generate livelihood opportunities and strengthen the economic conditions of the local people in the region.

Overall, by the SWOT analysis of the area (Table 2) it can be inferred that these are lifelines for the

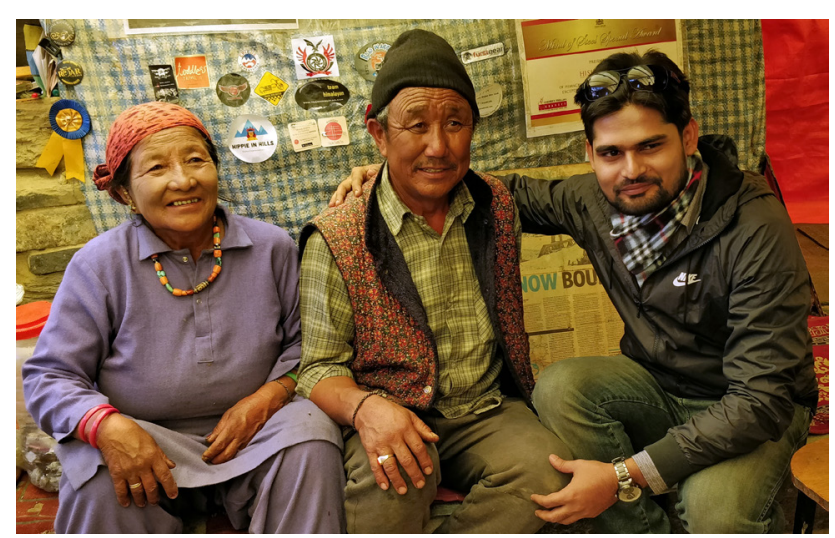

Fig. 6. Bodh Dorjee and his wife Chandra with author: the owners of Chandra dhaba at Batal locals as well as the tourists as it is enterprising and source of livelihood for the former while life saving for the later. The geomorphosites based tourism in the region can play a pivotal role for its economic development and seasonal dhaba economy can be a main contributor to this if regulated properly by in time by the government and local people together. The improved government aid can help locals in sustaining their livelihood and at the same time help in the economic growth of the district.

The advent of new technologies in agriculture together with improved communication lines in geo-Zone IV, have made life of the Lahaul and Spiti communities easier. The role of government in providing aid and subsides to the poor and marginalized communities has a significant impact on the day to day life of the locals. The tap water facilities and the rural electrification i.e. for 100 per cent of the households certainly seem to ease out the miseries of hash terrain and extreme events. But, still the role of geotourism based on geodiversity (geomorphosites and geosites) is undermined by the government agencies. The district has a vast reserve of georesources and geomorphosites that can accrue large number of tourists from all across the world. The glacial lakes, lacustrine sediments, erosional and depositional features of the tethyan sediments are few of many phys-

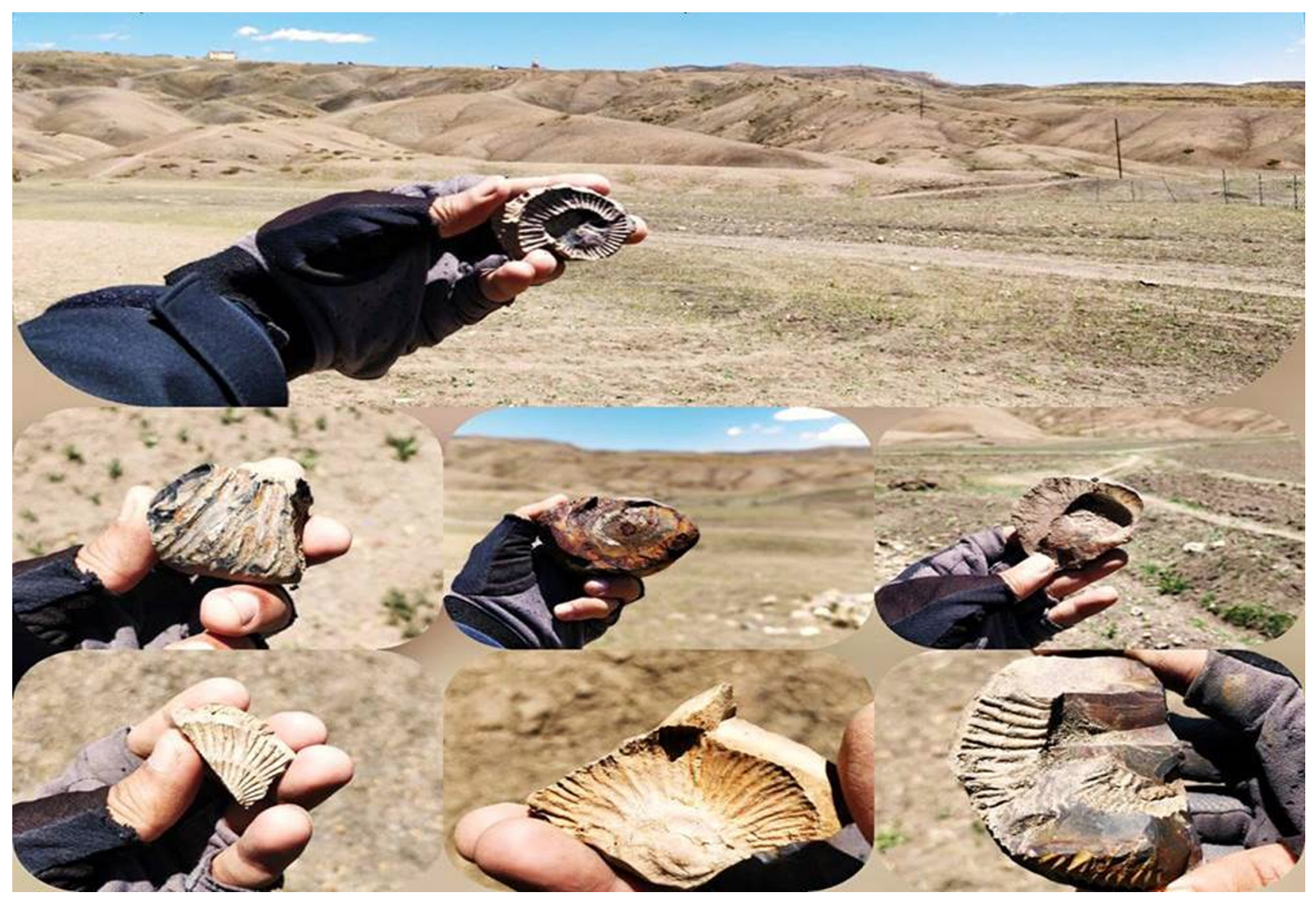

Fig. 7. Fossils at Langza - various shapes and patterns of ammonite 
Table 2. Strength Weakness Opportunities and Threat (SWOT) Analysis of Lahaul and Spiti

\begin{tabular}{|c|c|c|c|}
\hline Strength & Weakness & Opportunities & Threat \\
\hline $\begin{array}{l}\text { Beautiful, cold desert } \\
\text { landscape surrounded by } \\
\text { mountain passes on all sides }\end{array}$ & $\begin{array}{l}\text { Vulnerable to Natural } \\
\text { Hazards and seasonal in } \\
\text { character }\end{array}$ & $\begin{array}{l}\text { Immense Geotourism } \\
\text { potential in the region with } \\
\text { the modern technological } \\
\text { development. }\end{array}$ & $\begin{array}{l}\text { Deformation of Landscape } \\
\text { due to increasing } \\
\text { developmental Pressures. }\end{array}$ \\
\hline $\begin{array}{l}\text { Source of Major Glaciers, } \\
\text { Glacial lakes and Rivers }\end{array}$ & $\begin{array}{l}\text { Lack of Awareness among } \\
\text { the planning bodies }\end{array}$ & $\begin{array}{l}\text { Immense potential to } \\
\text { harness the hydropower, } \\
\text { water rafting and other } \\
\text { sports activities. }\end{array}$ & $\begin{array}{l}\text { Ecological balance may be } \\
\text { disturbed without proper } \\
\text { research and development } \\
\text { methods }\end{array}$ \\
\hline $\begin{array}{l}\text { Indigenous Knowledge } \\
\text { preserved }\end{array}$ & $\begin{array}{l}\text { Lack of awareness among } \\
\text { the research fraternities }\end{array}$ & $\begin{array}{l}\text { The knowledge can be } \\
\text { harnessed and cure for many } \\
\text { ailments can be discovered } \\
\text { in the region }\end{array}$ & $\begin{array}{l}\text { Loss of Knowledge due } \\
\text { to ageing population and } \\
\text { outmigration of the youth }\end{array}$ \\
\hline $\begin{array}{l}\text { Cultural Uniqueness } \\
\text { (Buddhist Practices) }\end{array}$ & $\begin{array}{l}\text { Remote landscape restricts } \\
\text { the cultural interface from } \\
\text { other areas }\end{array}$ & $\begin{array}{l}\text { Immense Cultural tourism } \\
\text { potential (Ancient } \\
\text { monasteries and cultural } \\
\text { practices. }\end{array}$ & $\begin{array}{l}\text { Unchecked tourism and } \\
\text { influence from outside may } \\
\text { fade the cultural uniqueness } \\
\text { over time. }\end{array}$ \\
\hline $\begin{array}{l}\text { Unique floral/faunal } \\
\text { diversity }\end{array}$ & $\begin{array}{l}\text { Lack of Awareness amongst } \\
\text { the tourists as well as } \\
\text { planners. }\end{array}$ & $\begin{array}{l}\text { Immense potential to create } \\
\text { a Geo/Eco park/fossil park } \\
\text { etc. and help in sustainable } \\
\text { livelihood generation. }\end{array}$ & $\begin{array}{l}\text { Degradation of landscape } \\
\text { due to natural and } \\
\text { anthropogenic hazards may } \\
\text { lead to extinction. }\end{array}$ \\
\hline
\end{tabular}

ical features in the landscape that has tremendous potential for higher geotourism in the region; which has evolved and grown over the last decade. The ancient reserves of Tethyan sediments and lacustrine deposits in the area make it a paradise for geoscientists who have explored and documented many findings. But, unfortunately it's yet to receive a weightage in terms of geoconservation and management by the government. The exposed rock surfaces, various glacio-fluvial deposits and the associated human activities make the area unique in character. The role of seasonal dhabas can't be undermined in the economic development of the area; as they play a pivotal role of facilitator in the season economy based on geotourism in the entire district.

\section{Concluding remarks and summary}

However, to promote geotourism in the area, first a detailed inventory of geodiversity (geomorphosites/ geomorphoheritage) sites is required. It is obvious that in the development of a peer-reviewed national inventory, different academic and professional organizations, research institutions and university departments should be involved. There is also a need for a body to setup, maintain and regularly update the database regarding the existing and potential geomorphosites in the area. There is also a need to have simple and informative geomorphodiversity maps for different regions (national, state, site specific) to facilitate more geotourism activities. As suggested by Kale (2014), the systematic mapping of landforms is required to achieve a national assessment of India's landforms. Such maps will also facilitate in determining the outstanding geoheritage sites/areas in India.

Several institutions and organisations such as the Geological Survey of India (GSI), the Geological Society of India, Archaeological survey of India and the Ministry of Earth Sciences (MoES) as well as the university departments across the country have a key role to play in this overdue activity. A district geomorphosites inventory and a full understanding of the scientific, cultural, aesthetic, economic, and ecological value of the geomorphological wonders are vital from the standpoint of geotourism promotion and conservation of Lahaul and Spiti's rich geoheritage.

During the open season in Lahaul and Spiti, the potential threat to the landscape in many vital areas like Kunzum pass (geo-Zone-I), have increased with the increasing use of mountain bikes, motorbikes and all-terrain vehicles that often leads to soil compaction, erosion or gullying on slopes. This needs to be addressed by the road monitoring agencies as well as the local communities. Seasonal economy has to be strengthened in the region through the coordination of local people, self-help groups, local government and the NGOs. The potential geotourism sites and associated livelihood opportunities have to be further identified and developed. The villages such as Darcha and Sarchu in Lahaul valley, and Kibber, Langza, Komic, Gulling, Mikkim and Mud in Spiti valley have fossiliferous rocks (geo-Zone-II and V). It may be inferred that the region has tremendous potential for establishments of fossil parks. The analysis of geomorphosites for defining the priority areas for geoconservation would be useful to define the protected areas, geoecological zones, fossil parks and geoparks. 
Therefore, the assessment of geodiversity (geomorphosites and geosites) and geotourism potential should be considered as a tool for nature conservation (geoconservation), natural resource management and formulation of geotourism strategies in the area. Last but not least, interface (interaction) of the abiotic stimuli (in terms of seasonal opening and closing of mountain passes and melting of snow) and corresponding human response finds itself the best fit framework to study the geotourism based seasonal economy in the Lahaul and Spiti district.

\section{Acknowledgement}

The author is grateful to the University of Delhi for institutional support and all the authors and scholars whose work have been referred in the article. The author is extremely grateful to two anonymous reviewers for very insightful comments on the original content of the article.

\section{References}

Bruschi V.M., Cendrero A., Albertos J.A.C., 2011. A statistical approach to the validation and optimization of geoheritage assessment procedures. Geoheritage 3: 131-149.

Comanescu L., Nedelea A., 2010. Analysis of some representative geomorphosites in the Bucegi Mountains: between scientific evaluation and tourist perception. Area 42(4): 406- 416.

Coratza P., Giusti C., 2005. Methodological proposal for the assessment of the scientific quality of geomorphosites. Il Quaternario 18(1): 305-313.

Coratza P., Reynard E., Zwolinski Zb., 2018. Geodiversity and Geoheritage: Crossing Disciplines and Approaches. Geoheritage 10: 525-526. DOI: 10.1007/s12371-018-0333-9.

Dowling R.K., 2013. Global Geotourism - An Emerging Form of Sustainable Tourism. Czech Journal of Tourism 2(2): 59-79. DOI: $10.2478 /$ cjot-2013-0004.
Gray M. (2013). Geodiversity: Valuing and conserving abiotic nature. Wiley Blackwell, Chichester.

Hassan S., 2012. A tourism demand based method of geosites assessment on geotourism prioritization modeling: The case of Razavi Khorasan Province. Journal of Hospitality Management and Tourism 3: 82-94. 10.5897/JHMT12.009.

Kale V.S., 2014. Geomorphosites and Geoheritage Sites in India. In: V.S.Kale (ed), Landscapes and Landforms of India, Springer, Dordrecht: 247-267.

Krishnanand, Raman V.A.V. 2019. Geographical Analysis of Geotourism based Seasonal Economy in Lahaul and Spiti, Himachal Pradesh (India). GeoJournal of Tourism and Geosites 24(1): 118-132.

Neches I.-M., 2013. From Geomorphosite Evaluation to Geotourism Interpretation. Case Study: The Sphinx of Romania's Southern Carpathians. GeoJournal of Tourism and Geosites 12(2): $145-162$.

Panizza M., 2001. Geomorphosites: concepts, methods and examples of geomorphological survey. Chinese Science Bulletin (Suppl.) 46: 4-6.

Panizza M., Piacente S., 2003. Geomorfologia Culturale. Pitagora Editrice, Bologna, 350 pp.

Pereira P., Pereira D., 2010. Methodological guidelines for geomorphosite assessment. Géomorphologie: Relief, Processus, Environnement 1(3): 215-222.

Pica A., Vergari F., Fredi P., Del Monte M., 2016. The Aeterna Urbs Geomorphological Heritage (Rome, Italy). Geoheritage 8(1): $31-42$.

Reynard E., Fontana G., Koźlik L., Capozza C., 2007. A method for assessing scientific and additional values of geomorphosites. Geographica Helvetica 62 (3): 148-158.

Shayan S., Sharifikia M., Zare G.R., 2011. Evaluating the geomorphotourism potential of landforms based on Praloong method (Case Study: Darab Township). Arid Regions Geographic Studies 1(2): 73-91.

The Times of India, 2010. Saviour couple of Spiti valley. Online: timesofindia.indiatimes.com/2010/india/Saviour-couple-of-Spiti valley/articleshow/6094462.cms (accessed 20.10.2019).

Yamani M., Negahban S., Harabadi S., Alizadeh M., 2012. Geomorphotourism and Comparison of Methods for the Assessment of Geomorphosites in Tourism Development (Case Study: Hormozgan Provice). Journal of Tourism Planning and Development 1(1): 83-104.

Zwoliński Zb., 2004. Geodiversity. In: Encyclopedia of Geomorphology, A.Goudie (ed.), Routledge: 417-418. 